\title{
Wastewater-grown Algae Pellets and Paste as Fertilizers for Containerized Crops
}

\author{
J Austin Gimondo ${ }^{1}$ and Christopher J. Currey \\ Department of Horticulture, Iowa State University, 106 Horticulture Hall, \\ Ames, IA 50011
}

Darren H. Jarboe
Center for Crops Utilization Research, 1041 Food Sciences Building, Ames,
IA 50011

Martin Gross

Department of Food Science and Human Nutrition, 2312 Food Sciences Building, Ames, IA 50011

\section{William R. Graves \\ Department of Horticulture, Iowa State University, 106 Horticulture Hall, Ames, IA 50011}

Additional index words. bio-based, marigold, tomato, sweet corn, Tagetes patula, Solanum lycopersicum, Zea mays

\begin{abstract}
Drawbacks of traditional synthetic fertilizer led us to explore a biologically based (bio-based) alternative. Our objective was to quantify the efficacy of wastewatergrown algae pellets and pastes harvested from rotating algal biofilm systems as fertilizers for three crops, 'Honeycomb' marigold (Tagetes patula L.), 'Beefsteak' tomato (Solanum lycopersicum L.), and 'Ambrosia' sweet corn (Zea mays L.). Factorial experiments were designed for each crop with fertilizer type (algae pellets, algae paste, a synthetic controlled-release fertilizer, or a commercially available bio-based fertilizer from wastewater treatment) and substrate (commercial or custom-made) as factors. Shoot growth, shoot nutrient concentration, and substrate $\mathrm{pH}$ and electrical conductivity (EC) were affected by fertilizer, substrate, or their interaction. Algae pellets and paste supplied nutrients to all three species effectively, increasing shoot size, dry weight, perceived health, and nutrient concentrations compared with unfertilized controls. Notwithstanding some variability among crops, performance of algal materials was similar to that of the synthetic fertilizer and better than that of the commercial bio-based fertilizer. As a bio-based fertilizer that supplies plants with recycled nutrients sequestered from wastewater, wastewater-grown algae can reduce the impacts of mineral nutrition management in container-crop production by partially supplanting synthetic fertilizer use.
\end{abstract}

The United States greenhouse crop industry is a high-value sector. Containerized crops, including potted flowering plants, annual bedding plants, and garden crops, accounted for nearly 3.4 billion U.S. dollars of greenhouse crop sales in 2015 (U.S. Department of Agriculture, 2016). High production densities, plant quality requirements, and the use of soilless substrates with little or no available mineral nutrients contribute to

Received for publication 10 Aug. 2018. Accepted for publication 11 Dec. 2018.

We gratefully acknowledge Peter Lawlor for assistance in the greenhouse; Zachary Hudson, Jaden Rich, and Max Gangestad for assistance with experiment setup and data collection; and the Leopold Center for Sustainable Agriculture for funding.

${ }^{1}$ Corresponding author. E-mail: gimondo@iastate. edu. the necessity for fertilization. Synthetic fertilizers account for nearly $50 \%$ of all $\mathrm{N}$ applications globally (West and Marland, 2002) and are the primary source of nutrients used in horticultural production. However, drawbacks of synthetic fertilizers, including environmental impacts associated with their production and use, have led to demand for sustainable alternatives (Carpenter et al., 1998; Pelletier et al., 2008).

Nonsynthetic and biologically based (biobased) materials show potential (Burnett et al., 2016; McCabe et al., 2016; Schrader et al., 2013). Bio-based fertilizers are more sustainable and environmentally benign than synthetic fertilizers (Pelletier et al., 2008). Many bio-based sources have potential as fertilizers, including coproducts of plant processing, such as soy flour and vegetable oils; animal manures; fish emulsion; coproducts of wastewater treatment, like sludge and millorganite; and algae (Chaney et al., 1980;
Mulbry et al., 2005; Nelson et al., 2010; Schrader et al., 2013). Of these sources, algae, specifically that sourced from wastewater treatment systems, has shown particular promise for providing an alternative to synthetic fertilizers for container-crop production (Mulbry et al., 2005, 2006; Solovchenko et al., 2016).

The potential benefits of using wastewatergrown algae to replace synthetic fertilizers are multifaceted. Along with most other biobased fertilizers, algae supply plant nutrients in organic forms, as opposed to the inorganic forms in synthetic fertilizers (Mulbry et al., 2005). Organic forms of nitrogen must undergo biological mineralization before becoming soluble and thus have reduced mobility compared with their inorganic counterparts, leading to a lower likelihood of nutrient loss via leaching (Gaskell and Smith, 2007; Solovchenko et al., 2016). In addition, unlike synthetic fertilizers, the fixation of nutrients in algal biomass occurs through biological processes, avoiding the ecological impacts associated with synthetic fertilizer production (Boelee et al., 2011; Mulbry et al., 2005). Furthermore, through sequestration of plant nutrients from wastewater streams, wastewatergrown algae serves the dual purpose of wastewater treatment and nutrient recycling (Boelee et al., 2011; Cai et al., 2013; Mulbry et al., 2005). However, despite these advantages, low production capacity and cost efficiency, along with the lack of applied research on specific application effects, have limited the adoption of these materials in container-crop production.

Although algal biomass production is heavily studied, actual algal biomass production has remained limited (Christenson and Sims, 2011). Until recently, methods for generating significant quantities of algal biomass required high-energy inputs, and whereas low-energy alternatives like raceway ponds exist, they produce insufficient quantities of algae. Furthermore, harvesting algae from these systems is difficult and accounts for more than $20 \%$ of production cost (Davis et al., 2011). New systems using fixation of algae to biofilms, like rotating algal biofilm (RAB) systems, have mitigated many drawbacks and significantly increased the efficiency of algal biomass production by increasing the volume of algae produced, reducing energy inputs required, simplifying the harvesting processes, and using wastewater streams as nutrient sources (Gross et al., 2013, 2015).

There are few reports of research on wastewater-grown algae as a container-crop fertilizer. Mulbry et al. $(2005,2006)$ and Coppens et al. (2016) assessed algae grown during the treatment of animal waste effluents as fertilizer. Mulbry et al. (2005, 2006) grew seedlings of corn and cucumber ( $\mathrm{Cucu}$ mis sativa L.) with dried algal biomass, whereas Coppens et al. (2016) grew tomatoes with algae-bacteria flocs. Plants supplied with algae in these studies had increased growth and visual quality compared with unfertilized controls. However, there has been no work measuring the fertilizing effect 
of algae harvested from municipal wastewater treatment systems, nor as a fertilizer for containerized floricultural crops. Additional applied research with these materials therefore is warranted.

We evaluated the efficacy of wastewatergrown algae paste and pellets as fertilizers for containerized french marigolds, tomato, and sweet corn. These algal materials are easily incorporated into the substrates used in container-crop production, and we expected them to provide a slow release of nutrients for plant uptake. We hypothesized that both algae paste and algae pellets will serve as effective fertilizers, and that plants supplied with these materials would be similar in size and perceived health to those provided with synthetic fertilizers. Our specific objective was to compare the growth and perceived health of plants fertilized with wastewatergrown algal materials with those traits of plants fertilized with two commercially available fertilizers, a synthetic controlledrelease fertilizer (CRF) and a bio-based wastewater treatment coproduct that supplied $\mathrm{N}$ in an organic form.

\section{Materials and Methods}

Algae fertilizer production. Algae was grown in simulated municipal wastewater in RAB systems (Gross et al., 2013). Most algae were Scenedesmus sp., Pediastrum sp., and Chlorella sp. (M. Gross, personal communication). Algae dried to $20 \%$ moisture content were pelletized with a flat die pellet press (MZL-200; Muyang, Yangzhou, China). Algae paste was harvested directly from the RAB system. Algae were analyzed for total nitrogen $(\mathrm{N})$ via the Kjedahl method, and phosphorus $(\mathrm{P})$ and potassium $(\mathrm{K})$ were measured with an inductively coupled argon plasma atomic emission spectrophotometer (Ciros CCD ICP-AES; SPECTRO Analytical Instruments, Kleve, Germany).

Fertilizer application. Pellets and paste of algae were used alongside a CRF [Florikan CORE 90-d release 16.0N-2.2P-9.1K (Florikan ESA, Sarasota, FL)] and a commercially available bio-based fertilizer [Milorganite $6.0 \mathrm{~N}-1.7 \mathrm{P}-0.0 \mathrm{~K}$ (Milorganite, Milwaukee, WI)] (Table 1). All fertilizers were applied by weight with a standardized concentration of $\mathrm{N}$ that corresponded to the label recommendation of the CRF, $641.2 \mathrm{~g} \mathrm{~N} / \mathrm{m}^{3}$. Fertilizer treatments were weighed and incorporated throughout the substrate for each plant individually.

Table 1. Nutrient concentrations [nitrogen $(\mathrm{N})$, phosphorus $(\mathrm{P})$, and potassium $(\mathrm{K})$ ] of wastewater-grown algae, controlled-release fertilizer (CRF), and commercial bio-based fertilizer used to grow french marigold (Tagetes patula L. 'Honeycomb'), tomato (Solanum lycopersicum L. 'Beefsteak'), and sweet corn (Zea mays L. 'Ambrosia').

\begin{tabular}{lrcc}
\hline & \multicolumn{3}{c}{ Nutrient concn (\%) } \\
\cline { 2 - 4 } Fertilizer type & $\mathrm{N}$ & $\mathrm{P}$ & $\mathrm{K}$ \\
\hline Wastewater-grown algae & 5.2 & 5.1 & 0.6 \\
CRF $^{z}$ & 16.0 & 2.2 & 9.1 \\
Commercial bio-based fertilizer $^{y}$ & 6.0 & 1.7 & 0.0 \\
\hline
\end{tabular}

${ }^{\mathrm{z}} \mathrm{CRF}$ was Florikan CORE (16.0N-2.2P-9.1K) 90-d release (Florikan ESA, Sarasota, FL).

${ }^{\mathrm{y}}$ Commercial bio-based fertilizer was Milorganite $6.0 \mathrm{~N}-1.7 \mathrm{P}-0.0 \mathrm{~K}$ (Milorganite, Milwaukee, WI).
9813-6; Hanna Instruments, Smithfield, RI). Plants were then visually evaluated and rated by three trained horticulturists blind to treatments. Values of 0 to 5 , where a rating of 5 indicated a plant that appeared robust and healthy, 3 a satisfactory plant, and 0 a dead plant, were assigned based on the visual assessment. Qualities considered by raters were plant size, color, presence of chlorosis, and other symptoms of nutrient-related problems. Height, width at widest point, and width perpendicular to widest point of shoots were recorded. Growth index was calculated by adding shoot height to the average of the two width measurements and then dividing this sum by two. Only height was measured for plants of corn and is reported in place of growth index. Shoots were then severed at the substrate surface, dried in a forced-air oven maintained at $67{ }^{\circ} \mathrm{C}$ for $3 \mathrm{~d}$, and shoot dry weight (SDW) was recorded. Three shoot samples were randomly selected from each treatment group to be analyzed for shoot $\mathrm{N}, \mathrm{P}$, and $\mathrm{K}$ concentrations. Shoot $\mathrm{N}$ was determined with a $\mathrm{CN}$ analyzer (Vario MAX CN Analyzer; elementar Americas, Inc., Mt. Laurel, NJ), whereas P and K were determined with an inductively coupled argon plasma atomic emission spectrophotometer.

Statistical analysis. Two-way analyses of variance $(\alpha=0.05)$ and mean-separation with Tukey's honestly significant difference test at $P \leq 0.05$ were performed by using RStudio (Version 1.1.414; RStudio, Boston, MA). Means for health rating, growth index, and SDW were determined from all replicates (individual plants; $\mathrm{n}=7$ ), whereas means for nutritional results are from three randomly selected replicates per treatment $(n=3)$.

\section{Results}

Marigold. Fertilizer and substrate had interactive effects on substrate $\mathrm{pH}$ and $\mathrm{EC}$ of marigold (Table 2). Substrate $\mathrm{pH}$ ranged from 4.7 to 5.9 in the commercial substrate and 5.8 to 6.7 in the custom substrate, and EC ranged from 1.59 to $4.27 \mathrm{dS} \cdot \mathrm{m}^{-1}$ in the commercial substrate and 0.68 to $2.04 \mathrm{dS} \cdot \mathrm{m}^{-1}$ in the custom substrate (Table 3 ).

Fertilizer source and substrate had interactive effects on SDW, growth index, and health (Table 2; Fig. 1). The SDW of marigolds provided with algae paste in the commercial substrate was similar to that of CRF-fertilized plants, $36 \%$ greater than that of plants fertilized with the commercial biobased fertilizer, and $89 \%$ greater than that of unfertilized plants. In the custom substrate, algae pellets, algae paste, and CRF led to marigolds with the greatest dry weight. Marigolds grown with algae paste or algae pellets in the commercial substrate were similar in size to plants supplied with CRF or commercial bio-based fertilizer and larger than unfertilized plants (Fig. 1). In the custom substrate, marigolds provided with either algal material were larger than plants provided with the commercial bio-based fertilizer or unfertilized plants but were similar to plants provided with CRF. Marigolds fertilized with algae paste or algae pellets were rated 
greatest in both substrates, although CRFsupplied marigolds were rated similarly in the commercial substrate and received scores similar to those of plants fertilized with algae pellets in the custom substrate (Fig. 1). On average, marigolds fertilized with algal materials
Table 2. Analyses of variance for fertilizer $(\mathrm{F})$ and substrate $(\mathrm{S})$ on health rating, growth index, shoot dry weight (SDW), shoot nutrient concentrations [nitrogen $(\mathrm{N})$, phosphorus $(\mathrm{P})$, and potassium $(\mathrm{K})$ ], substrate $\mathrm{pH}$, and substrate EC of french marigold (Tagetes patula L. 'Honeycomb'), tomato (Solanum lycopersicum L. 'Beefsteak'), and sweet corn (Zea mays L. 'Ambrosia') grown for 5 weeks. Plants were supplied $641.2 \mathrm{~g} \mathrm{~N} / \mathrm{m}^{3}$ from one of four fertilizer sources (algae paste, algae pellets, synthetic controlled-release fertilizer, or a commercial bio-based fertilizer) or unfertilized. Fertilizer treatments were incorporated throughout one of two soilless substrates, a commercial mix that included a fertilizer starter charge or a custom mix.

\begin{tabular}{|c|c|c|c|}
\hline & Fertilizer & Substrate & $\mathrm{F} \times \mathrm{S}$ \\
\hline & & Marigold & \\
\hline Health rating & $* * *$ & $* * *$ & $* * *$ \\
\hline Growth index & $* * *$ & $* * *$ & $* * *$ \\
\hline SDW & $* * *$ & $* * *$ & $* *$ \\
\hline $\mathrm{N}(\%)$ & $* * *$ & $* *$ & NS \\
\hline P (\%) & $* * *$ & NS & NS \\
\hline K $(\%)$ & $* * *$ & $* * *$ & NS \\
\hline $\mathrm{pH}$ & $* * *$ & $* * *$ & $* * *$ \\
\hline \multirow[t]{2}{*}{ EC } & $* * *$ & $* * *$ & $* * *$ \\
\hline & & Tomato & \\
\hline Health rating & $* * *$ & $* * *$ & NS \\
\hline Growth index & $* * *$ & $* * *$ & $* * *$ \\
\hline SDW & $* * *$ & $* * *$ & NS \\
\hline $\mathrm{N}(\%)$ & $* * *$ & $* * *$ & $* * *$ \\
\hline P (\%) & $* * *$ & * & $* *$ \\
\hline K $(\%)$ & $* *$ & ** & NS \\
\hline $\mathrm{pH}$ & $* * *$ & $* * *$ & $* * *$ \\
\hline \multirow[t]{2}{*}{ EC } & $* * *$ & $* * *$ & $* * *$ \\
\hline & & Sweet corn & \\
\hline Health rating & $* * *$ & * & * \\
\hline Height & $* * *$ & $* * *$ & $* *$ \\
\hline SDW & $* * *$ & $* * *$ & NS \\
\hline $\mathrm{N}(\%)$ & $* * *$ & $* * *$ & NS \\
\hline P (\%) & $* * *$ & NS & NS \\
\hline $\mathrm{K}(\%)$ & NS & $* *$ & NS \\
\hline $\mathrm{pH}$ & *** & $* * *$ & $* * *$ \\
\hline $\mathrm{EC}$ & *** & *** & $* * *$ \\
\hline
\end{tabular}

NS, $* * *, * *$ Nonsignificant or significant at $P \leq 0.05,0.01$, or 0.001 , respectively.

Table 3. Effect of fertilizer type and substrate on PourThru leachate $\mathrm{pH}$ and electrical conductivity (EC) for french marigold (Tagetes patula L. 'Honeycomb'), tomato (Solanum lycopersicum L. 'Big Beef'), and sweet corn (Zea mays L. 'Ambrosia') grown for 5 weeks. Plants were supplied $641.2 \mathrm{~g} \mathrm{~N} / \mathrm{m}^{3}$ from one of four fertilizer sources [algae paste, algae pellets, synthetic controlled-release fertilizer (CRF), or a commercial bio-based fertilizer] or unfertilized. Fertilizer treatments were incorporated throughout one of two soilless substrates, a commercial mix that included a fertilizer starter charge or a custom mix.

\begin{tabular}{llccc}
\hline & \multicolumn{4}{c}{ Substrate } \\
\cline { 2 - 5 } Fertilizer type & \multicolumn{2}{c}{ Commercial } & \multicolumn{2}{c}{ Custom } \\
\cline { 2 - 5 } \cline { 3 - 5 } Algae paste & $\mathrm{pH}$ & $\mathrm{EC}\left(\mathrm{dS} \cdot \mathrm{m}^{-1}\right)$ & $\mathrm{pH}$ & $\mathrm{EC}\left(\mathrm{dS} \cdot \mathrm{m}^{-1}\right)$ \\
Algae pellet & $5.9 \mathrm{~A}^{\mathrm{z} \mathrm{a}^{\mathrm{y}}}$ & $1.59 \mathrm{Ac}$ & $5.8 \mathrm{Aa}$ & $1.58 \mathrm{Aa}$ \\
CRF & $5.4 \mathrm{Bbc}$ & $2.58 \mathrm{Ab}$ & $6.4 \mathrm{Aab}$ & $1.51 \mathrm{Bab}$ \\
Commercial bio-based & $5.1 \mathrm{Bc}$ & $2.26 \mathrm{Abc}$ & $6.3 \mathrm{Ab}$ & $1.73 \mathrm{Aa}$ \\
Unfertilized $^{\mathrm{w}}$ & $4.7 \mathrm{Bd}$ & $4.27 \mathrm{Aa}$ & $6.5 \mathrm{Aab}$ & $2.04 \mathrm{Ba}$ \\
& $5.6 \mathrm{Bab}$ & $1.97 \mathrm{Abc}$ & $6.7 \mathrm{Aa}$ & $0.68 \mathrm{Bb}$ \\
Algae paste & & & Tomato & \\
Algae pellet & $5.7 \mathrm{Ba}$ & $2.29 \mathrm{Abc}$ & $6.0 \mathrm{Aa}$ & $1.35 \mathrm{Bbc}$ \\
CRF & $5.6 \mathrm{Aa}$ & $4.02 \mathrm{Aa}$ & $5.6 \mathrm{Abc}$ & $2.04 \mathrm{Bab}$ \\
Commercial bio-based & $4.9 \mathrm{Bb}$ & $4.21 \mathrm{Aa}$ & $5.3 \mathrm{Ac}$ & $2.08 \mathrm{Bab}$ \\
Unfertilized & $4.9 \mathrm{Bb}$ & $3.03 \mathrm{Ab}$ & $5.8 \mathrm{Aab}$ & $2.38 \mathrm{Ba}$ \\
& $5.9 \mathrm{Aa}$ & $1.61 \mathrm{Ac}$ & $6.1 \mathrm{Aa}$ & $0.83 \mathrm{Ac}$ \\
Algae paste & & & Sweet corn & \\
Algae pellet & $5.6 \mathrm{Bab}$ & $3.80 \mathrm{Aab}$ & $5.7 \mathrm{Ab}$ & $1.86 \mathrm{Bab}$ \\
CRF & $5.3 \mathrm{Bb}$ & $2.64 \mathrm{Abc}$ & $5.8 \mathrm{Aab}$ & $1.55 \mathrm{Bab}$ \\
Commercial bio-based & $5.7 \mathrm{Bab}$ & $2.01 \mathrm{Acd}$ & $5.6 \mathrm{Ab}$ & $1.10 \mathrm{Bab}$ \\
Unfertilized & $4.8 \mathrm{Bc}$ & $4.35 \mathrm{Aa}$ & $5.9 \mathrm{Aab}$ & $2.11 \mathrm{Ba}$ \\
Un & $5.9 \mathrm{Ba}$ & $1.00 \mathrm{Ad}$ & $6.1 \mathrm{Aa}$ & $0.64 \mathrm{Ab}$ \\
\hline
\end{tabular}

${ }^{\mathrm{z}}$ Uppercase letters within a crop indicate mean separation between substrates within a fertilizer by Tukey's honestly significant difference (HSD) test at $P \leq 0.05(\mathrm{n}=7)$.

${ }^{\mathrm{y}}$ Lowercase letters within a crop indicate mean separation among fertilizers within a substrate by Tukey's HSD test at $P \leq 0.05(\mathrm{n}=7)$.

${ }^{\mathrm{x}} \mathrm{CRF}$ was Florikan CORE 16.0N-2.2P-9.1K 90-d release (Florikan ESA, Sarasota, FL).

${ }^{\mathrm{w}}$ Commercial bio-based fertilizer was Milorganite $6.0 \mathrm{~N}-1.7 \mathrm{P}-0.0 \mathrm{~K}$ (Milorganite, Milwaukee, WI). received health ratings 2.0 or 2.6 greater than ratings of unfertilized plants in the commercial or custom substrates, respectively.

Shoot nutrient concentrations were affected by fertilizer and substrate treatments but not by their interaction (Tables 2,4 , and 5). Shoot $\mathrm{N}$ ranged from $1.69 \%$ to $6.77 \%$. Plants grown in the commercial substrate had shoot $\mathrm{N}$ and $\mathrm{K}$ concentrations $0.62 \%$ and $0.39 \%$ greater than those of plants grown in the custom substrate, respectively. Marigolds supplied either algal material had similar shoot $\mathrm{N}$ concentrations, which were more than three times greater than those of unfertilized plants. Treatments of algae paste and pellets led to marigold shoot $P$ concentrations greater than those of the marigolds in the CRF or unfertilized treatments (Table 4). Marigolds supplied with either algal material or with $\mathrm{CRF}$ had shoot $\mathrm{K}$ concentrations greater than those of unfertilized plants.

Tomato. Fertilizer and substrate had interactive effects on substrate $\mathrm{pH}$ and EC (Table 2). Across fertilizers, substrate $\mathrm{pH}$ ranged from 4.9 to 5.9 in the commercial substrate and 5.3 to 6.1 in the custom substrate, and EC ranged from 1.61 to $4.21 \mathrm{dS} \cdot \mathrm{m}^{-1}$ in the commercial substrate and 0.83 to $2.38 \mathrm{dS} \cdot \mathrm{m}^{-1}$ in the custom substrate (Table 3).

Fertilizer and substrate affected SDW and health rating (Table 2; Fig. 2), and their interaction affected growth index (Table 2; Fig. 3). Plants grown with algae paste were the largest, accumulating $10 \%, 82 \%$, or $232 \%$ more weight than plants grown with CRF, commercial bio-based, or no fertilizer, respectively (Fig. 2). SDW of plants fertilized with algae pellets was also larger than SDW of plants fertilized with the commercial biobased fertilizer by $50 \%$ and larger than that of unfertilized plants by $174 \%$. Plants grown in commercial substrate averaged $1.93 \mathrm{~g}$ more weight than those grown in the custom substrate. In the commercial substrate, growth index ranged from 21.6 to 31.6 and was greatest for plants fertilized with algae paste or CRF, and lowest in unfertilized plants (Fig. 3). Growth index of plants supplied with algae pellets were similar to those of CRF-supplied plants. In the custom substrate, growth index ranged from 14.8 to 29.0 and was greatest in plants supplied with either algal material or CRF. Health ratings were increased by 0.6 on average for plants grown in the commercial substrate (Fig. 2). Tomatoes supplied with algae paste, algae pellets, or CRF received the greatest health ratings. However, ratings of plants fertilized with algae paste or the commercial bio-based fertilizer were similar.

There were interactive effects of fertilizer and substrate on shoot $\mathrm{N}$ and $\mathrm{P}$ concentrations (Tables 2 and 6). When grown with either algal material in the commercial substrate, shoot $\mathrm{N}$ and $\mathrm{P}$ concentrations were greater than those of unfertilized plants (Table 6). Shoot N concentration of algae pellet-fertilized plants was similar to that of tomatoes grown with the commercial biobased fertilizer, whereas shoot $\mathrm{N}$ of plants provided with algae paste was not different 

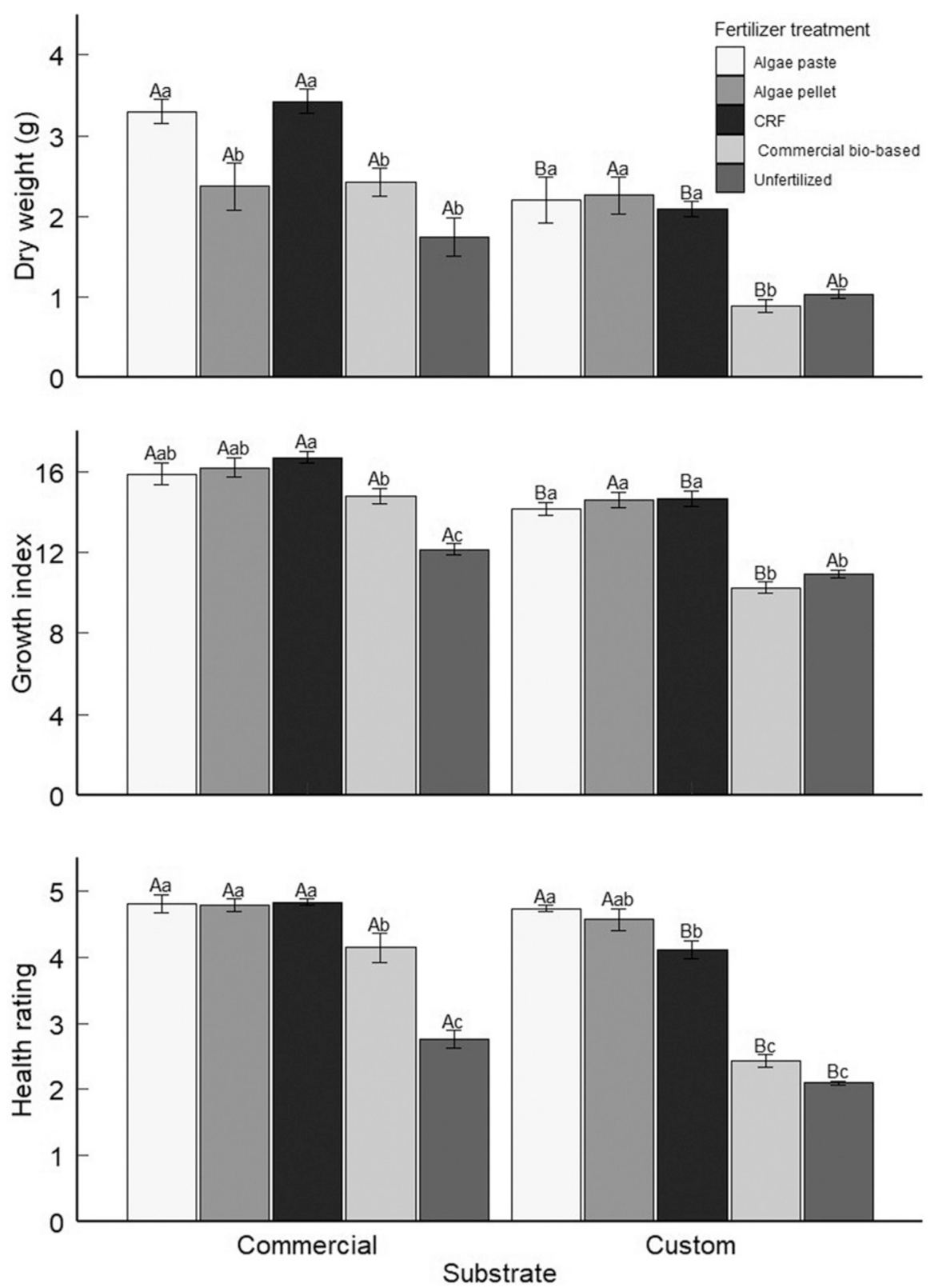

Fig. 1. Shoot dry weight, growth index, and health rating of french marigolds (Tagetes patula $\mathrm{L}$. 'Honeycomb') grown for 5 weeks in containers. Plants were supplied $641.2 \mathrm{~g} \mathrm{~N} / \mathrm{m}^{3}$ from one of four fertilizer sources [algae paste, algae pellets, synthetic controlled-release fertilizer (CRF), or a commercial bio-based fertilizer] or unfertilized. Fertilizer treatments were incorporated throughout one of two soilless substrates, a commercial mix that included a fertilizer starter charge or a custom mix. Mean separation by Tukey's honestly significant difference test at $P \leq 0.05(\mathrm{n}=7)$ is indicated by uppercase lettering for separation between substrates within a fertilizer and lowercase lettering for separation among fertilizers within a substrate. The interaction of fertilizer and substrate affected shoot dry weight, growth index, and health rating $(P \leq 0.001)$.

from plants that received CRF. In the custom substrate, shoot $\mathrm{N}$ concentrations were greater for all fertilized plants than for plants left unfertilized (Table 6). Plants supplied either algal material had similar shoot $\mathrm{N}$ concentrations, which were greater than those of CRF-fertilized plants and unfertilized plants and lower than those of the tomatoes grown with the commercial bio-based fertilizer. In both substrates, shoot $\mathrm{P}$ concentration of plants provided algae paste was the greatest, followed by that of plants grown with algae pellets (Table 6). With the exception of algae and 5.6 to 6.1 in the custom substrate, and EC ranged from 1.00 to $4.35 \mathrm{dS} \cdot \mathrm{m}^{-1}$ in the commercial substrate and 0.64 to $2.11 \mathrm{dS} \cdot \mathrm{m}^{-1}$ in the custom substrate (Table 3 ).

SDW was affected by fertilizer and substrate, and their interaction affected height and health ratings (Table 2). Sweet corn grown in the commercial substrate accumulated $1.4 \mathrm{~g}$ more dry weight than plants grown in the custom substrate (Fig. 4). Algae paste, algae pellets, and CRF led to the greatest SDW. Sweet corn supplied with algae pellets accumulated $39 \%$ more weight than plants grown with the commercial bio-based fertilizer and $133 \%$ more weight than unfertilized plants. SDW of plants provided with algae paste was similar to that of plants grown with commercial bio-based fertilizer, and 107\% greater than SDW of unfertilized plants. Plant height ranged from 96.6 to $119.1 \mathrm{~cm}$, and from 77.9 to $113.1 \mathrm{~cm}$ in the commercial and custom substrates, respectively (Fig. 5). Algae pellets and CRF treatments led to the tallest plants in both substrates, although in the commercial substrate plants supplied with the commercial bio-based fertilizer were also the tallest. Algae paste led to plants of similar height to those provided with algae pellets in the commercial substrate and CRF in custom substrate. Health rating was affected by the interaction of fertilizer and substrate. In the commercial substrate, health ratings of plants supplied with either algal material were not different from those of other fertilized plants, but algae pastefertilized plants were rated 0.7 greater than unfertilized plants (Fig. 5). In the custom substrate, health ratings of sweet corn grown with either algal material were 0.8 greater than those of unfertilized plants and 0.3 greater than those of plants supplied with commercial bio-based fertilizer but 0.6 lower than those of CRF-fertilized plants (Fig. 5).

Shoot $\mathrm{N}$ concentration was affected by fertilizer and substrate treatment, but not their interaction (Table 2). The custom substrate led to shoot $\mathrm{N}$ concentrations $0.6 \%$ greater than those of plants in the commercial substrate (Table 5). Shoot N concentration was greatest in plants supplied with the commercial bio-based fertilizer and lowest in unfertilized plants (Table 8). The two algal materials led to plants with similar shoot $\mathrm{N}$ concentrations, which were greater than those of plants grown with CRF or no fertilizer. Shoot $P$ concentration was affected only by fertilizer treatment. Algae paste led to the greatest shoot $\mathrm{P}$ concentrations, followed by algae pellet and commercial biobased treatments (Table 8). Treatments of CRF led to the lowest shoot $\mathrm{P}$ concentration. Shoot $\mathrm{P}$ concentration was similar between algae paste- and algae pellet-fertilized plants and was greater in plants fertilized with algae paste than in plants grown with CRF, commercial bio-based fertilizer, or no fertilizer (Table 8). Fertilizer treatment did not affect shoot $\mathrm{K}$ concentrations, but the mean concentration for plants in the commercial substrate exceeded that of plants in the custom substrate by $0.65 \%$ (Table 5 ). 
Table 4. Effect of fertilizer type on shoot nutrient concentration [nitrogen $(\mathrm{N})$, phosphorus $(\mathrm{P})$, and potassium (K)] of french marigold (Tagetes patula L. 'Honeycomb') grown for 5 weeks. Plants were supplied $641.2 \mathrm{~g} \mathrm{~N} / \mathrm{m}^{3}$ from one of four fertilizer sources [algae paste, algae pellets, synthetic controlled-release fertilizer (CRF), or a commercial bio-based fertilizer] or unfertilized. Fertilizer treatments were incorporated throughout one of two soilless substrates, a commercial mix that included a fertilizer starter charge or a custom mix. Data are pooled across substrates.

\begin{tabular}{lccc}
\hline & \multicolumn{3}{c}{ Shoot nutrient concn (\%) } \\
\cline { 2 - 4 } Fertilizer type & $\mathrm{N}$ & $\mathrm{P}$ & $\mathrm{K}$ \\
\hline Algae paste & $5.80 \mathrm{~b}^{\mathrm{z}}$ & $0.96 \mathrm{a}$ & $2.23 \mathrm{a}$ \\
Algae pellet & $5.96 \mathrm{~b}$ & $0.73 \mathrm{~b}$ & $1.84 \mathrm{~b}$ \\
CRF $^{\mathrm{y}}$ & $4.80 \mathrm{c}$ & $0.50 \mathrm{c}$ & $2.23 \mathrm{a}$ \\
Commercial bio-based $^{\mathrm{x}}$ & $6.73 \mathrm{a}$ & $0.37 \mathrm{c}$ & $1.69 \mathrm{bc}$ \\
Unfertilized & $1.74 \mathrm{~d}$ & $0.20 \mathrm{~d}$ & $1.44 \mathrm{c}$ \\
\hline
\end{tabular}

${ }^{\mathrm{z}}$ Letters in columns indicate mean separation among fertilizers within crop by Tukey's honestly significant difference test at $P \leq 0.05(\mathrm{n}=6)$.

${ }^{\mathrm{y}} \mathrm{CRF}$ was Florikan CORE 16.0N-2.2P-9.1K 90-d release (Florikan ESA, Sarasota, FL).

${ }^{\mathrm{x}}$ Commercial bio-based fertilizer was Milorganite $6.0 \mathrm{~N}-1.7 \mathrm{P}-0.0 \mathrm{~K}$ (Milorganite, Milwaukee, WI).

Table 5. Effect of substrate type on shoot nutrient concentration [nitrogen $(\mathrm{N})$ or potassium $(\mathrm{K})$ ] of marigold (Tagetes patula L. 'Honeycomb'), tomato (Solanum lycopersicum L. 'Beefsteak'), and sweet corn (Zea mays L. 'Ambrosia') grown for 5 weeks. Plants were supplied $641.2 \mathrm{~g} \mathrm{~N} / \mathrm{m}^{3}$ from one of four fertilizer sources [algae paste, algae pellets, synthetic controlled-release fertilizer (CRF), or a commercial bio-based fertilizer] or unfertilized. Fertilizer treatments were incorporated throughout one of two soilless substrates, a commercial mix that included a fertilizer starter charge or a custom mix. Data were pooled across fertilizer treatments.

\begin{tabular}{|c|c|c|c|}
\hline \multirow[b]{3}{*}{ Nutrient } & \multicolumn{2}{|c|}{ Shoot nutrient concn (\%) } & \multirow[b]{3}{*}{ Significance } \\
\hline & \multicolumn{2}{|c|}{ Substrate } & \\
\hline & Commercial & Custom & \\
\hline & \multicolumn{2}{|c|}{ Marigold } & \\
\hline $\mathrm{N}$ & 4.81 & 4.19 & ** \\
\hline K & 1.94 & 1.55 & $* * *$ \\
\hline \multicolumn{4}{|c|}{ Tomato } \\
\hline K & 1.33 & 1.09 & ** \\
\hline \multicolumn{4}{|c|}{ Sweet corn } \\
\hline $\mathrm{N}$ & 2.66 & 3.26 & $* * *$ \\
\hline $\mathrm{K}$ & 1.62 & 0.97 & $* *$ \\
\hline
\end{tabular}

\section{Discussion}

Our results demonstrate that wastewatergrown algae paste and pellets provide plantavailable nutrients to container-grown crops and can be used as fertilizers for the production of marigolds, tomatoes, and sweet corn. Notwithstanding some variability among crops, these algae-based fertilizers perform at least as well as conventional CRF, and as well as or better than the commercial bio-based fertilizer we used. As a bio-based fertilizer that sequesters and recycles nutrients from wastewater streams, wastewater-grown algae could reduce the environmental impacts related to fertility management in container-crop production by partially supplanting conventional synthetic fertilizers.

Overall, growth and quality of plants provided wastewater-grown algae pellets or paste exceeded those of unfertilized plants and were similar to those of CRF-supplied plants (Figs. 1-3). Our results are consistent with related work with wastewater-grown algal materials to produce tomatoes with algae-bacteria flocs (Coppens et al., 2016) and corn in growth chambers (Mulbry et al., 2005, 2006). Coppens et al. (2016) used algae-bacteria flocs harvested from an aquaculture wastewater treatment system as a fertilizer for production of tomato plants. Plants of tomato provided with flocs were
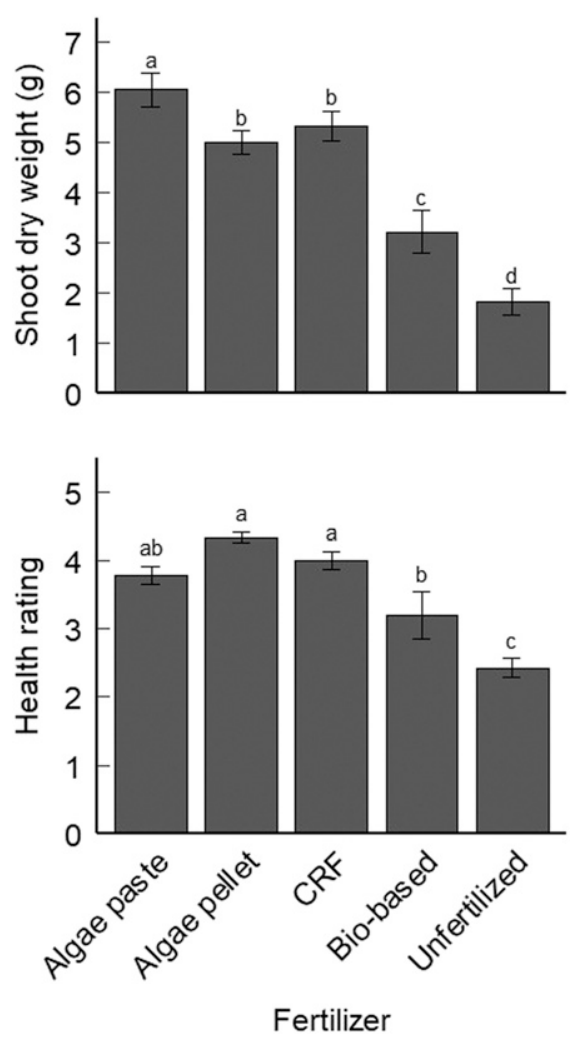

Fig. 2. Shoot dry weight and health rating of tomato plants (Solanum lycopersicum L. 'Big Beef') grown for 5 weeks in containers. Plants were supplied $641.2 \mathrm{~g} \mathrm{~N} / \mathrm{m}^{3}$ from one of four fertilizer sources [algae paste, algae pellets, synthetic controlled-release fertilizer (CRF), or a commercial bio-based fertilizer] or unfertilized. Fertilizer treatments were incorporated throughout one of two soilless substrates a commercial mix that included a fertilizer starter charge or a custom mix. Data were pooled across substrates. Lettering indicates mean separation among fertilizer treatments by Tukey's honestly significant difference test at $P \leq 0.05(\mathrm{n}=14)$. Fertilizer and substrate affected shoot dry weight and health rating $(P \leq 0.001)$.

algae were similar in size and nutrient content to seedlings provided with conventional fertilizers at the same rate. Mulbry et al. (2006) included standard and high application rates of dried algae sourced from laboratory and pilot-scale wastewater treatment systems. At a standard rate, seedlings provided with algal materials were similar to conventionally fertilized plants. We are unaware of research to evaluate wastewater-grown algae as a fertilizer for bedding plants, precluding direct comparisons. However, Bi et al. (2010) grew marigolds successfully with bio-based fertilizers, consistent with our findings. Furthermore, as reviewed by Burnett et al. (2016) and Treadwell et al. (2007), bio-based fertilizers typically are effective for the production of containerized crops when they supply mineral nutrients at rates similar to synthetic fertilizers. Our results align well with the literature by demonstrating the efficacy of wastewater-grown algae paste and pellets as viable fertilizers for marigolds, tomatoes, and sweet corn.

Shoot nutrient concentrations help to explain the growth responses we observed. All fertilized marigolds were within or above recommended ranges for $\mathrm{N}$ (Table 2 ), whereas some treated tomato (Table 4) and corn (Table 5) were not (Bryson et al., 2014; Gibson et al., 2007). No symptoms of $\mathrm{N}$ deficiency were observed among fertilized tomatoes, despite CRF-supplied tomato $\mathrm{N}$ concentrations being below the recommended range (Bryson et al., 2014). Only corn provided with algae paste or the commercial bio-based fertilizer had sufficient shoot $\mathrm{N}$ concentrations; plants in other treatments were visibly deficient in $\mathrm{N}$ (Bryson et al., 2014). The frequency of $\mathrm{N}$ deficiency in corn likely indicates that the $\mathrm{N}$ application rate was too low. Although fertilizers were applied at a standardized rate of total $\mathrm{N}$, differences in the concentrations of mineral and organic $\mathrm{N}$ in the materials most likely led to variation in the amount of plantavailable $\mathrm{N}$ from each fertilizer. Although some treatments led to plants with shoot $\mathrm{P}$ concentrations below their recommended range (Tables 2-4), no symptoms of P deficiency were evident among fertilized plants (Bryson 


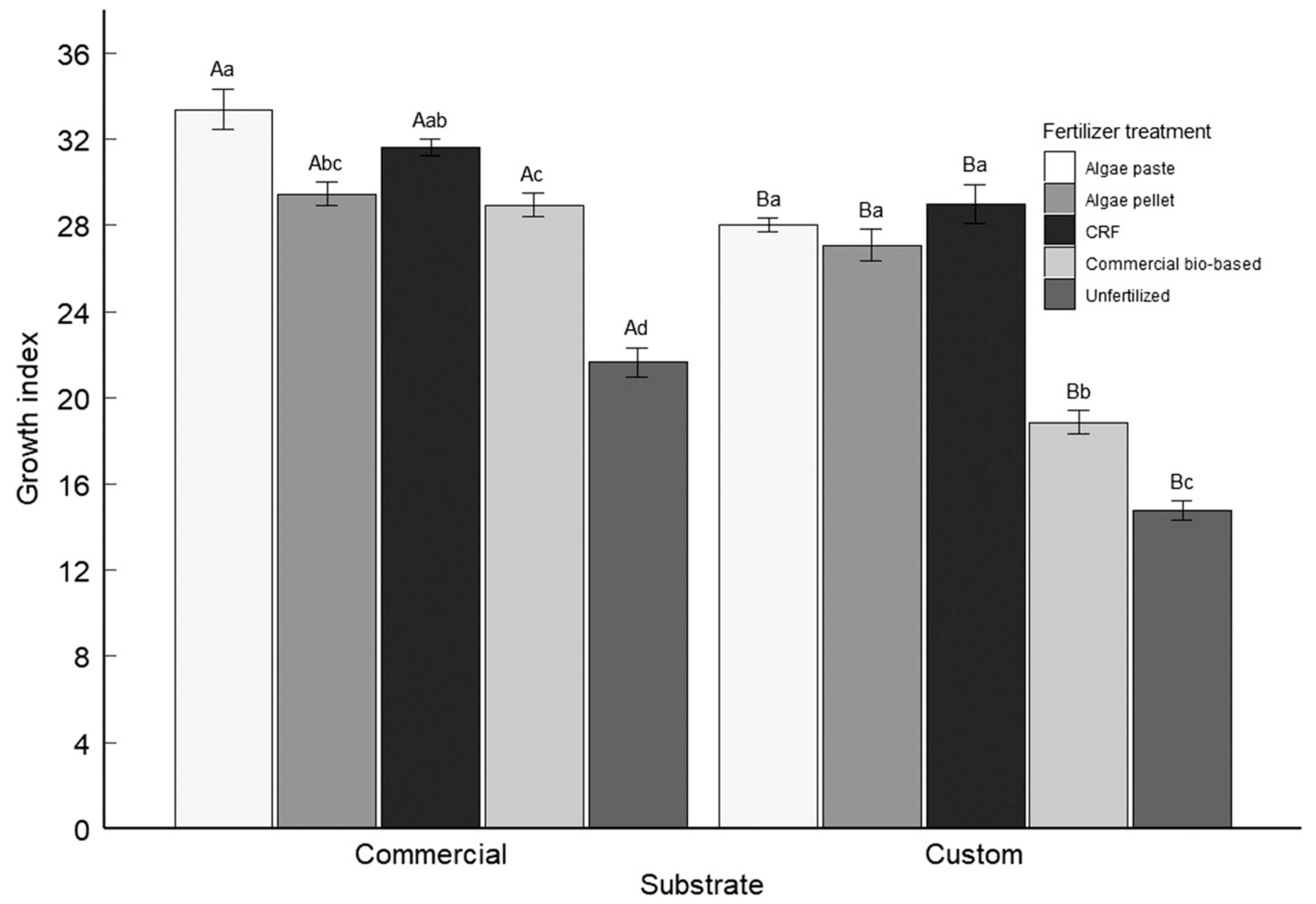

Fig. 3. Growth index of tomato plants (Solanum lycopersicum L. 'Big Beef') grown for 5 weeks in containers. Plants were supplied $641.2 \mathrm{~g} \mathrm{~N} / \mathrm{m}^{3}$ from one of four fertilizer sources [algae paste, algae pellets, synthetic controlled-release fertilizer (CRF), or a commercial bio-based fertilizer] or unfertilized. Fertilizer treatments were incorporated throughout one of two soilless substrates, a commercial mix that included a fertilizer starter charge or a custom mix. Mean separation by Tukey's honestly significant difference test at $P \leq 0.05(\mathrm{n}=7)$ is indicated by uppercase lettering for separation between substrates within a fertilizer and lowercase lettering for separation among fertilizers within a substrate. The interaction of fertilizer and substrate affected shoot dry weight, growth index, and health rating $(P \leq 0.001)$.

Table 6. Effect of fertilizer type and substrate on shoot nutrient concentrations [nitrogen $(\mathrm{N})$ and phosphorus (P)] of tomato (Solanum lycopersicum L. 'Big Beef') grown for 5 weeks. Plants were supplied $641.2 \mathrm{~g} \mathrm{~N} / \mathrm{m}^{3}$ from one of four fertilizer sources [algae paste, algae pellets, synthetic controlled-release fertilizer (CRF), or a commercial bio-based fertilizer] or unfertilized. Fertilizer treatments were incorporated throughout one of two soilless substrates, a commercial mix that included a fertilizer starter charge or a custom mix.

\begin{tabular}{llc}
\hline & \multicolumn{2}{c}{ Shoot nutrient concn (\%) } \\
\cline { 2 - 3 } Fertilizer type & \multicolumn{1}{c}{$\mathrm{N}$} & $\mathrm{P}$ \\
\hline Commercial substrate & & \\
Algae paste & $2.86 \mathrm{~B}^{\mathrm{z}} \mathrm{bc}^{\mathrm{y}}$ & $1.28 \mathrm{Aa}$ \\
Algae pellet & $3.57 \mathrm{Bab}^{\mathrm{y}}$ & $0.74 \mathrm{Ab}$ \\
CRF $^{\mathrm{x}}$ & $2.21 \mathrm{Acd}$ & $0.20 \mathrm{Ac}$ \\
Commercial bio-based $^{\mathrm{w}}$ & $4.11 \mathrm{Ba}$ & $0.44 \mathrm{Ac}$ \\
$\quad$ Unfertilized & $1.14 \mathrm{Ad}$ & $0.27 \mathrm{Ac}$ \\
Custom substrate & & \\
Algae paste & $5.28 \mathrm{Ab}$ & $1.62 \mathrm{Aa}$ \\
Algae pellet & $4.89 \mathrm{Ab}$ & $0.97 \mathrm{Ab}$ \\
CRF & $2.89 \mathrm{Ac}$ & $0.15 \mathrm{Ad}$ \\
Commercial bio-based & $7.34 \mathrm{Aa}$ & $0.60 \mathrm{Ac}$ \\
Unfertilized & $1.48 \mathrm{Ad}$ & $0.09 \mathrm{Bd}$ \\
\hline
\end{tabular}

${ }^{\mathrm{z}}$ Uppercase letters indicate mean separation between substrates within a fertilizer by Tukey's honestly significant difference (HSD) test at $P \leq 0.05(\mathrm{n}=3)$.

${ }^{\mathrm{y}}$ Lowercase letters indicate mean separation among fertilizers within a substrate by Tukey's HSD test at $P \leq$ $0.05(\mathrm{n}=3)$.

${ }^{\mathrm{x}}$ CRF was Florikan CORE 16.0N-2.2P-9.1K 90-d release (Florikan ESA, Sarasota, FL).

${ }^{\mathrm{w}}$ Commercial bio-based fertilizer was Milorganite 6.0N-1.7P-0.0K (Milorganite, Milwaukee, WI).

et al., 2014). In addition, the trend in deficient shoot $\mathrm{P}$ concentrations was not reflected in any of the plant growth metrics. Shoot K concentrations were considerably lower than recommended ranges for all crops (Bryson et al., 2014). Although below the sufficient range, shoot $\mathrm{K}$ concentrations of marigold (Table 2) were above the critical minimum range reported by Pitchay (2003), and no deficiency symptoms were present (Gibson et al., 2007). Symptoms of K deficiency were apparent in tomato plants that received algae paste or commercial bio-based fertilizer treatments in the custom substrate and all corn plants (Tables 3 and 4). The severity of deficiency symptoms followed the trend of shoot $\mathrm{K}$ concentrations for these plants; those with the lowest shoot $\mathrm{K}$ concentration showed the most severe deficiency symptoms. Compositional differences in fertilizer materials led to differential application rates of $\mathrm{P}$ and $\mathrm{K}$, but tissue nutrient concentrations did not reflect application rates. However, the complete absence of $\mathrm{K}$ in the commercial bio-based fertilizer likely contributed to the suppressed vigor of plants in that treatment.

Shoot $\mathrm{N}$ and $\mathrm{P}$ concentrations of marigolds fertilized with bio-based materials were similar to values observed by $\mathrm{Bi}$ et al. (2010) for marigolds supplied with organic fertilizers, and shoot $\mathrm{K}$ concentrations were comparatively lower in our marigolds. This difference likely was due to the greater $\mathrm{K}$ 
Table 7. Effect of fertilizer type on shoot potassium concentration of tomato (Solanum lycopersicum L. 'Beefsteak') grown for 5 weeks. Plants were supplied $641.2 \mathrm{~g} \mathrm{~N} / \mathrm{m}^{3}$ from one of four fertilizer sources [algae paste, algae pellets, synthetic controlled-release fertilizer (CRF), or a commercial bio-based fertilizer] or unfertilized. Fertilizer treatments were incorporated throughout one of two soilless substrates, a commercial mix that included a fertilizer starter charge or a custom mix. Data were pooled across substrates.

\begin{tabular}{lc}
\hline Fertilizer type & $\begin{array}{c}\text { Shoot nutrient } \\
\text { concn }(\%)\end{array}$ \\
\hline Algae paste & $0.89 \mathrm{~b}^{\mathrm{z}}$ \\
Algae pellet & $1.32 \mathrm{a}$ \\
CRF $^{\mathrm{y}}$ & $1.32 \mathrm{a}$ \\
Commercial bio-based & $1.19 \mathrm{ab}$ \\
Unfertilized & $1.33 \mathrm{a}$ \\
\hline
\end{tabular}

${ }^{\mathrm{z}}$ Letters indicate mean separation among fertilizers within crop by Tukey's honestly significant difference test at $P \leq 0.05(\mathrm{n}=6)$.

${ }^{\mathrm{y}} \mathrm{CRF}$ was Florikan CORE 16.0N-2.2P-9.1K 90-d release (Florikan ESA, Sarasota, FL).

${ }^{\mathrm{x}}$ Commercial bio-based fertilizer was Milorganite $6.0 \mathrm{~N}-1.7 \mathrm{P}-0.0 \mathrm{~K}$ (Milorganite, Milwaukee, WI).

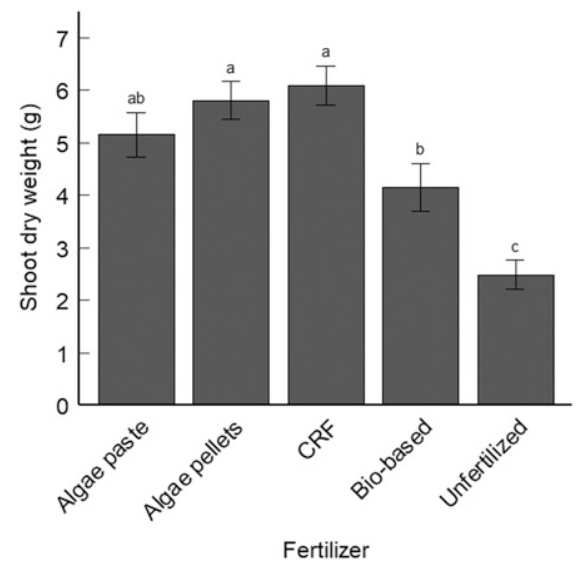

Fig. 4. Shoot dry weight of sweet corn (Zea mays L. 'Ambrosia') grown for 5 weeks in containers. Plants were supplied $641.2 \mathrm{~g} \mathrm{~N} \cdot \mathrm{m}^{-3}$ from one of four fertilizer sources [algae paste, algae pellets, synthetic controlled-release fertilizer (CRF), or a commercial bio-based fertilizer] or unfertilized. Fertilizer treatments were incorporated throughout one of two soilless substrates, a commercial mix that included a fertilizer starter charge or a custom mix. Data were pooled across substrate. Lettering indicates mean separation among fertilizer treatments by Tukey's honestly significant difference test at $P \leq$ $0.05(\mathrm{n}=14)$. Fertilizer and substrate affected shoot dry weight $(P \leq 0.001)$.

concentration of the organic fertilizer used by Bi et al. (2010). Shoot nutrient concentrations for tomato followed a similar trend when compared with tomatoes grown with algal flocs by Coppens et al. (2016); shoot $\mathrm{N}$ and $\mathrm{P}$ were similar between experiments, and shoot $\mathrm{K}$ was lower in algae-fertilized tomato plants in our work. However, despite similar fertilizer $\mathrm{K}$ concentrations for algal materials in both experiments, Coppens et al. (2016) reported concentrations of $\mathrm{K}$ in tomato shoots to be greater than $20 \%$, concentrations much greater than values reported in previous literature on $\mathrm{K}$ nutrition for tomato plants
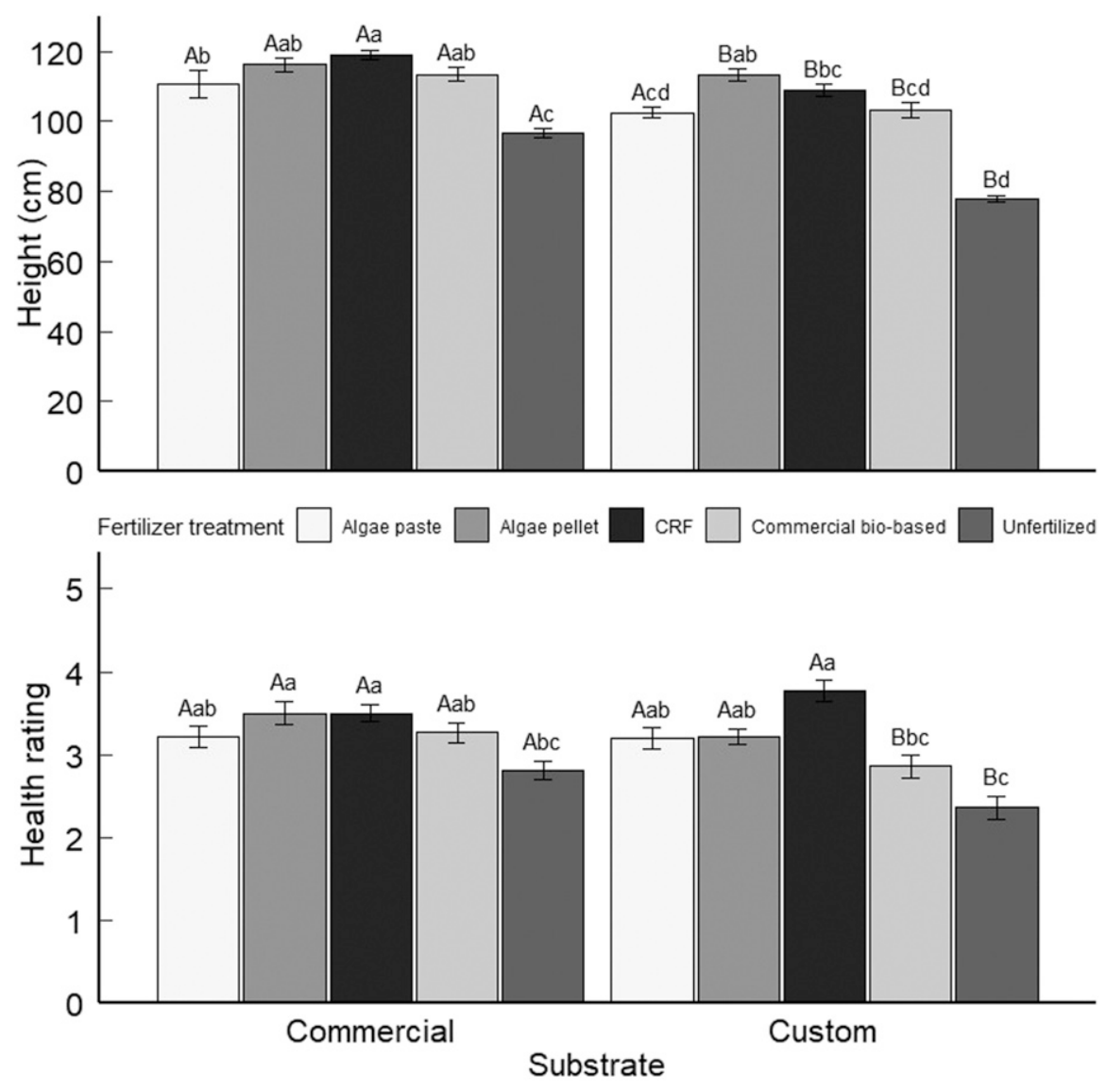

Fig. 5. Height and health ratings of sweet corn (Zea mays L. 'Ambrosia') grown for 5 weeks in containers. Plants were supplied $641.2 \mathrm{~g} \mathrm{~N} / \mathrm{m}^{3}$ from one of four fertilizer sources [algae paste, algae pellets, synthetic controlled-release fertilizer (CRF), or a commercial bio-based fertilizer] or unfertilized. Fertilizer treatments were incorporated throughout one of two soilless substrates, a commercial mix that included a fertilizer starter charge or a custom mix. Mean separation by Tukey's honestly significant difference test at $P \leq 0.05(\mathrm{n}=7)$ is indicated by uppercase lettering for separation between substrates within a fertilizer and lowercase lettering for separation among fertilizers within a substrate. The interaction of fertilizer and substrate affected height and health rating $(P \leq 0.001)$.

Table 8. Effect of fertilizer type on shoot nutrient concentration [nitrogen $(\mathrm{N})$ and phosphorus $(\mathrm{P})$ ] of sweet corn (Zea mays L. 'Ambrosia') grown for 5 weeks. Plants were supplied $641.2 \mathrm{~g} \mathrm{~N} / \mathrm{m}^{3}$ from one of four fertilizer sources [algae paste, algae pellets, synthetic controlled-release fertilizer (CRF), or a commercial bio-based fertilizer] or unfertilized. Fertilizer treatments were incorporated throughout one of two soilless substrates, a commercial mix that included a fertilizer starter charge or a custom mix. Data were pooled across substrates.

\begin{tabular}{lcc}
\hline & \multicolumn{3}{c}{ Shoot nutrient concn (\%) } \\
\cline { 2 - 3 } Fertilizer type & $\mathrm{N}$ & $\mathrm{P}$ \\
\hline Algae paste & $3.68 \mathrm{~b}^{\mathrm{z}}$ & $0.95 \mathrm{a}$ \\
Algae pellet & $3.22 \mathrm{~b}$ & $0.57 \mathrm{~b}$ \\
CRF $^{\mathrm{y}}$ & $2.27 \mathrm{c}$ & $0.18 \mathrm{~d}$ \\
Commercial bio-based $^{\mathrm{x}}$ & $4.40 \mathrm{a}$ & $0.43 \mathrm{bc}$ \\
Unfertilized $^{\text {nay }}$ & $1.25 \mathrm{~d}$ & $0.20 \mathrm{~cd}$ \\
\hline
\end{tabular}

${ }^{\mathrm{z}}$ Letters in columns indicate mean separation among fertilizers within crop by Tukey's honestly significant difference test at $P \leq 0.05(\mathrm{n}=6)$.

${ }^{\mathrm{y}} \mathrm{CRF}$ was Florikan CORE 16.0N-2.2P-9.1K 90-d release (Florikan ESA, Sarasota, FL).

${ }^{\mathrm{x}}$ Commercial bio-based fertilizer was Milorganite $6.0 \mathrm{~N}-1.7 \mathrm{P}-0.0 \mathrm{~K}$ (Milorganite, Milwaukee, WI).

(Besford and Maw, 1974). Nonetheless, compared with other work with bio-based fertilizers for tomato production (Rippy et al., 2004 ), shoot $\mathrm{K}$ concentration in our algaefertilized tomato was comparatively low. Shoot $\mathrm{N}$ and $\mathrm{P}$ concentrations in algaefertilized corn were similar to those reported by Mulbry et al. $(2005,2006)$ for seedlings grown with dried wastewater-grown algae. Shoot K concentration was not reported by
Mulbry et al. (2005, 2006). The capability of bio-based fertilizers to provide adequate $\mathrm{K}$ has been examined before in soy-based fertilizers (Nelson et al., 2010), and our results indicate that it will be an important consideration for future work with algal fertilizers as well. Based on nutrient concentrations of plants we grew, algal fertilizers alone may not be sufficient for plants that require high available $\mathrm{K}$ 
Treatment-related differences in substrate $\mathrm{pH}$ and EC were likely caused by differing rates of nutrient release and the forms of $\mathrm{N}$ released from the fertilizers. Substrate $\mathrm{pH}$ was generally within recommended ranges and, when substrate $\mathrm{pH}$ was outside the recommended values, no detrimental effects were observed (Cavins et al., 2008; Gibson et al., 2007; LeBude and Bilderback, 2009). Substrate EC was also within or above recommended levels (Gibson et al., 2007; LeBude and Bilderback, 2009), but no damage from excess soluble salts was apparent in the treatments with high EC. Across crops and fertilizer treatments, substrate $\mathrm{pH}$ was lower and EC was higher in the commercial substrate than in the custom substrate, which can be attributed to the presence of an initial fertilizer starter charge in the commercial substrate. As a measure of soluble salts, substrate EC increases with greater fertilizer application. Plant uptake of $\mathrm{NH}_{4}{ }^{+}$decreases soil $\mathrm{pH}$, whereas uptake of $\mathrm{NO}_{3}{ }^{-}$increases substrate $\mathrm{pH}$ (Matteson [sic] et al., 2009). The fertilizer charge in the commercial substrate likely provided additional $\mathrm{NH}_{4}^{+}$, leading to comparatively lower substrate $\mathrm{pH}$ in these treatments. The presence of the starter charge in the commercial substrate also could explain the interaction between substrate and fertilizer on substrate $\mathrm{pH}$ and EC. Release of soluble $\mathrm{N}$ from organic materials depends on the decomposition of organic matter and the mineralization of organic-N (Hartz et al., 2000). However, the growth of the microbes responsible for this decomposition can immobilize soluble $\mathrm{N}$ when the ratio of $\mathrm{C}$ to $\mathrm{N}$ surrounding an organic material is too high (Hartz et al., 2000). The presence of additional $\mathrm{N}$ from the starter fertilizer in the commercial substrate may have decreased the $\mathrm{C}: \mathrm{N}$ ratio surrounding the bio-based materials, leading to reduced immobilization, increased breakdown of organic materials, and greater concentrations of $\mathrm{N}$ released from the bio-based fertilizers. Greater release rates of soluble-N from the algae pellet treatments were likely the cause of increased substrate $\mathrm{EC}$ and lower substrate $\mathrm{pH}$ when this material was incorporated into commercial substrate.

Comparisons between life-cycle assessments of synthetic fertilizers and similar assessments of algae-based wastewater treatment and algal fertilizers indicate the potential for wastewater-grown algae fertilizers to reduce environmental impacts of containercrop fertilization (Boelee et al., 2011; Clarens et al., 2010; Pelletier et al., 2008; West and Marland, 2002). Whereas synthetic fertilizers require resource-intensive manufacturing processes, wastewater-grown algae recycles nutrients from waste streams biologically (Gouveia et al., 2016; West and Marland, 2002). In addition, when the environmental advantages of algae-based wastewater treatment over conventional nutrient-removal processes are considered, the benefits of these materials increase (Boelee et al., 2011; Fernández et al., 2012; Wang et al., 2010). Although previously limited by production bottlenecks, new technology has increased productivity of wastewater-grown algae, further expanding the prospects for these materials to be incorporated into container-crop production systems (Christenson and Sims, 2011).

\section{Conclusions}

This work demonstrates that wastewatergrown algal materials effectively provide plant nutrients to containerized crops and be used successfully as fertilizers. Despite some variability among crops, performance of algal materials was similar to that of a conventional synthetic fertilizer and exceeded that of the commercial bio-based fertilizer. By supplying recycled nutrients sequestered from wastewater streams to plants and offsetting synthetic fertilizer use, wastewatergrown algae fertilizers can reduce environmental impacts associated with fertilizer use in containerized crop production. Although this study has established the efficacy of using wastewater-grown algae to supply plants with essential nutrients, continued work examining nutrient release and leaching potential would be useful for further assessing algae-based materials as fertilizers. In addition, extending the work described here to additional crops, especially those sensitive to soluble salts and low $\mathrm{K}$ concentrations, would be valuable for expanding our understanding of algae-based fertilizers and easing the incorporation of these materials into production systems.

\section{Literature Cited}

Besford, R.T. and G.A. Maw. 1974. Uptake and distribution of potassium in tomato plants. Plant Soil 41:601-618.

Bi, G., W.B. Evans, J.M. Spiers, and A.L. Witcher. 2010. Effects of organic and inorganic fertilizers on marigold growth and flowering. HortScience 45:1373-1377.

Boelee, N.C., H. Temmink, M. Janssen, C.J.N. Buisman, and R.H. Wijffels. 2011. Nitrogen and phosphorus removal from municipal wastewater effluent using microalgal biofilms. Water Res. 45:5925-5933.

Bryson, G.M., H.A. Mills, D.N. Sasseville, J.B. Jones, Jr., and A.V. Barker. 2014. Plant analysis handbook III. Micro-macro Publishing, Athens, GA.

Burnett, S.E., N.S. Mattson, and K.A. Williams. 2016. Substrates and fertilizers for organic container production of herbs, vegetables, and herbaceous ornamental plants grown in greenhouses in the United States. Scientia Hort. 208:111-119

Cai, T., S.Y. Park, and Y. Li. 2013. Nutrient recovery from wastewater streams by microalgae: Status and prospects. Renew. Sustain. Energy Rev. 19:360-369.

Carpenter, S.R., N.F. Caraco, D.L. Correll, R.W Howarth, A.N. Sharpley, and V.H. Smith. 1998. Nonpoint pollution of surface waters with phosphorus and nitrogen. Ecol. Appl. 8:559-568.

Cavins, T.J., B.E. Whipker, and W.C. Fonteno. 2008. PourThru: A method for monitoring nutrition in the greenhouse. Acta Hort. 779:289-297.

Chaney, R.L., J.B. Munns, and H.M. Cathey. 1980. Effectiveness of digested sewage sludge compost in supplying nutrients for soilless potting media. J. Amer. Soc. Hort. Sci. 105:485-492.
Christenson, L. and R. Sims. 2011. Production and harvesting of microalgae for wastewater treatment, biofuels, and bioproducts. Biotechnol. Adv. 29:686-702

Clarens, A.F., E.P. Resurreccion, M.A. White, and L.M. Colosi. 2010. Environmental life cycle comparison of algae to other bioenergy feedstocks. Environ. Sci. Technol. 44:1813-1819.

Coppens, J., O. Grunert, S. Van De Hende, I Vanhoutte, N. Boon, G. Haesaert, and L. De Gelder. 2016. The use of microalgae as a high-value organic slow-release fertilizer results in tomatoes with increased carotenoid and sugar levels. J. Appl. Phycol. 28:2367-2377.

Davis, R., A. Aden, and P. Pienkos. 2011. Technoeconomic analysis of autotrophic microalgae for fuel production. Appl. Energy 88:3524 3531 .

Fernández, F.G.A., C.V. González-López, J.M. Fernández, and E.M. Grima. 2012. Conversion of $\mathrm{CO}_{2}$ into biomass by microalgae: How realistic a contribution may it be to significant $\mathrm{CO}_{2}$ removal? Appl. Microbiol. Biotechnol. 96:577-586.

Gaskell, M. and R. Smith. 2007. Nitrogen sources for organic vegetable crops. HortTechnology 17:431-441.

Gibson, J.L., D.S. Pitchay, A.L. Williams-Rhodes, B.E. Whipker, P.V. Nelson, and J.M. Dole. 2007. Nutrient deficiencies in bedding plants. Ball Publishing, Batavia, IL.

Gouveia, L., S. Graça, C. Sousa, L. Ambrosano, B Ribeiro, E.P. Botrel, P.C. Neta, A.F. Ferreira, and C.M. Silva. 2016. Microalgae biomass production using wastewater: Treatment and costs scale-up considerations. Algal Res. 16: $167-176$.

Gross, M., W. Henry, C. Michael, and Z. Wen. 2013. Development of a rotating algal biofilm growth system for attached microalgae growth with in situ biomass harvest. Bioresour. Technol. 150:195-201

Gross, M., D. Jarboe, and Z. Wen. 2015. Biofilmbased algal cultivation systems. Appl. Microbiol. Biotechnol. 99:5781-5789.

Hartz, T.K., J.P. Mitchell, and C. Giannini. 2000. Nitrogen and carbon mineralization dynamics of manures and composts. HortScience 35 : 209-212.

LeBude, A.V. and T.E. Bilderback. 2009. The pour-through extraction method: A nutrient management tool for nursery crops. N.C. State Univ. Coop. Ext. Bul. AG-717-W.

Matteson [sic], N., R. Leatherwood, and C. Peters. 2009. Nitrogen: All forms are not equal. Greenhouse Mgt. Production 29(6):18-20.

McCabe, K.G., C.J. Currey, J.A. Schrader, D. Grewell, J. Behrens, and W.R. Graves. 2016 Pelletized soy-based bioplastic fertilizers for container-crop production. HortScience 51: $1-10$.

Mulbry, W., S. Kondrad, and C. Pizzaro. 2006. Biofertilizers from algal treatment of dairy and swine manure effluents: Characterization of algal biomass as a slow release fertilizer. J. Veg. Sci. 12:107-125.

Mulbry, W., E.K. Westhead, C. Pizarro, and L. Sikora. 2005. Recycling of manure nutrients: Use of algal biomass from dairy manure treatment as a slow release fertilizer. Bioresour. Technol. 96:451-458.

Nelson, P.V., D.S. Pitchay, C.E. Niedziela, Jr., and N.C. Mingis. 2010. Effectiveness, ammonium impact and potassium adequacy of soybeanbase liquid fertilizer on bedding plants. J. Plant Nutr. 33:351-361.

Pelletier, N., N. Arsenault, and P. Tyedmers. 2008. Scenario modeling potential eco-efficiency gains 
from a transition to organic agriculture: Life cycle perspectives on Canadian canola, corn, soy, and wheat production. Environ. Mgt. 42: 989-1001.

Pitchay, D.S. 2003. Impact of 11 Elemental nutrient deficiencies on shoot and root growth, and foliar analysis standards of 13 ornamental taxa with emphasis on $\mathrm{Ca}$ and $\mathrm{B}$ control of root apical meristem development. North Carolina State Univ., Raleigh, PhD Diss.

Rippy, J.F.M., M.M. Peet, F.J. Louws, P.V. Nelson, D.B. Orr, and K.A. Sorensen. 2004. Plant development and harvest yields of greenhouse tomatoes in six organic growing systems. HortScience 39:223-229.
Schrader, J.A., G. Srinivasan, D. Grewell, K.G. McCabe, and W.R. Graves. 2013. Fertilizer effects of soy-plastic containers during crop production and transplant establishment. HortScience 48:724-731.

Solovchenko, A., A.M. Verschoor, and L.N Jablonowski. 2016. Phosphorus from wastewater to crops: An alternative path involving microalgae. Biotechnol. Adv. 34:550-564.

Treadwell, D.D., G.J. Hochmuth, R.C. Hochmuth, E.H. Simmone, L.L. Davis, W.L. Laughlin, Y. Li, T. Olczyk, R.K. Sprenkel, and L.S Osborne. 2007. Nutrient management in organic greenhouse herb production: Where are we now? HortTechnology 17:461-466.
U.S. Department of Agriculture. 2016. Floriculture crops 2015 summary. 2 Feb. 2018. <http:// www.nass.usda.gov/Statistics_by_State/New_ Jersey/Publications/Floriculture_Statistics/ F1F1Flor-06-19-2014.pdf>.

Wang, J., T. Zhang, and J. Chen. 2010. Operating costs for reducing total emission loads of key pollutants in municipal wastewater treatment plants in China. Water Sci. Technol. 62:9951002 .

West, T.O. and G. Marland. 2002. A synthesis of carbon sequestration, carbon emissions, and net carbon flux in agriculture: Comparing tillage practices in the United States. Agr. Ecosyst. Environ. 91:217-232. 